\title{
МОВНОСОЦІУМНА ОБ'ЄКТИВНО-ДИСКУРСИВНА МОТИВОВАНІСТЬ ПРЕСКРИПЦІЙ
}

3'ясовані особливості сучасних дискурсивно-правописних практик, що у своїй цілісній множині визначувані необхідністю: 1) зберегти тяглість функційного статусу прескрипцій із виявом їхнього кількісного та якісного регулятивно-інституційного використання; 2) об’єднати різні стихії стандартизації й кодифікації тих чи тих графем, сполук слів, морфологічних і синтаксичних форм; 3) обгрунтувати об'єктивний мовносоціумний статус національно-суспільних прескрипцій; 4) кумулятивно відбити нормативні тенденції використання форм, конструкцій; 5) максимально зреалізувати об'єктивні параметри нормативних тенденцій у синхронному вимірі.

Скваліфіковано статус семантичних чинників мотивації сучасної іменниково-морфологічної норми із простеженням іiі співвідносности i/чи неспіввідносности зі словотвірними маркерами, лексико-граматичними чинниками.

Ключові слова: правописна практика, дискурс, інституційний дискурс, дискурсивна практика, іменниково-морфологічна норма.

The features of modern discursive and spelling practices are clarified as being determined in their integral plurality by necessity: 1) to preserve the continuity of the functional status of prescriptions with the manifestation of their quantitative and qualitative regulatory and institutional use; 2) to combine different elements of standardization and codification of certain graphemes, word-combinations, morphological and syntactic forms; 3 ) to justify the objective linguo-social status of national-public prescriptions; 4) cumulatively discourage regulatory trends in the use of forms and constructions; 5) maximize the objective parameters of regulatory trends in synchronous measurement.

The paper describes the status of semantic factors of motivation of the modern substantive-morphological norm, and traces their correlation and/or non-correlation with word-formation markers, lexical and grammatical factors.

Keywords: spelling practice, discourse, institutional discourse, discursive practice, substantive-morphological norm.

0. Вступні зауваги. Правописна практика кожної мови має тривалу традицію, іiі основні компоненти мотивовані суспільними запитами: а) потреба загальнонаціонального використання відповідних правописних норм; б) формування правописного стандарту як основи його використання в усіх сферах суспільного життя - адміністративному, офіційно-діловому, культурно-естетичному та ін.; в) формування нормативно-кодифікованої тяглости для забезпечен-

* Дослідження виконано в межах фундаментального наукового проекту “Об'єктивна i суб'єктивна мовносоціумна граматика: комунікативно-когнітивний та прагматико-лінгвокомп'ютерний виміри” (0118U003137). 
ня повногенераційного та міжгенераційного функціювання літературно-мовних практик та ін. Правописні практики в їх суто прикладному аспекті неодноразово поставали в центрі студіювань вітчизняних дослідників, дидактів і практиків (Г. Голоскевич (Голоскевич 1929), М. Грушевський (Грушевський 1926), I. Кревецький (Кревецький 1929а, 1929б), М. Луців (Луців 1931), В. Німчук (Німчук 2002), І. Огієнко (Огієнко 1925, 1933), О. Синявський (Синявський 1931) С. Смаль-Стоцький (Смаль-Стоцький 1926) та ін.), розглядалися також дискусійні моменти в напрацюванні граматичних чи інших прескрипцій (I. Кревецький (Кревецький 1929а, 1929б), О. Палюх (Палюх 2014)). Не менш активно досліджувалися: історія українських правописних норм (О. Гузар (Гузар 1996), I. Фаріон (Фаріон 2014)), внесок окремих видатних постатей у становлення норм української літературної мови із зосередженням уваги на творчій спадщині I. Котляревського (М. Степаненко (Степаненко 2019)), П. Куліша (А. Даниленко (Danylenko 2016)), Т. Шевченка (С. Срмоленко (Срмоленко 2019), Л. Мацько (Мацько 2014)). Активними теоретичні й практичні правописні напрацювання постали в кінці XX - на початку XXI століть, коли актуальним стало не лише кодексне усталення правописних норм, суголосних національним потребам і запитам, розвитку Української держави, а й осмислення статусу та функційного навантаження правописних норм минулого, узагальнення основних напрямів «унормування, розунормування, перевнормування» українських правописних норм (С. Вакуленко (Вакуленко 2018)), прогнозування шляхів форм відродження проскрибованих граматичних, графічних, лексичних і стилістичних норм, аналіз їх рівноконкуретности i/чи функційно-обмеженого вияву. На заявлені питання можна відповісти аргументовано за умови адекватного розуміння мовносоціумного мотивування правописних прескрипцій, теоретичного узагальнення й кваліфікації, що й підтверджує актуальність пропонованого дослідження.

1. Постановка проблеми. Метою наукового студіювання є встановлення мовносоціумної мотивації художньо-естетичних та публіцистичних об'єктивно-правописних практик, орієнтованих на використання узусно мотивованих морфологічних та інших форм, із визначенням чинників їх динаміки та встановленням багатовекторности таких практик. Заявлена мета акуталізує необхідність вирішення низки питань: 1) скваліфікувати мовносоціумну мотивованість об'єктивно-правописних норм, сфокусованих на реалізацію узусних практик; 2) схарактеризувати основні чинники, що зумовлюють динаміки й конкурентність окремих правописних норм; 3) виявити доцентрові й відцентрові сили в сучасних дискурсивно-правописних практиках (на матеріалі низки іменниково-морфологічних форм); 4) визначити чинники тяглости правописних норм із окресленням домінування (↔ пріоритетности) окремих із них; 5) встановити типологійні вияви багатовекторности дискурсивно-правописних прексрипцій. Новизна дослідження полягає в дефінуванні мовносоціумної мотивації об'єктивно-дискурсивних практик і формування 3-поміж них пріоритетних. Теоретичне значення аналізу мотивоване осмисленням мовносоціумного простору функціювання дискурсивно-правописних практик, формування рівно- i/чи їх різноконкурентности. Практичне навантаження виконаного розгля- 
ду мотивоване можливістю використання його результатів в університетській практиці викладання навчальних дисциплін із питань правопису української та інших слов'янських мов.

Використане в назві статті слово мовносоиіумний є похідним від лексем мова й соиіум, його використання мотивоване потребою цілісного охоплення функціювання тих чи тих мовних утворень у певних корпоративних групах, соціальних зрізах мовної спільноти. Значення слова соиіум '2. Група людей, об'єднаних за якимись (професійними, культурними і т. ін. ознаками' (ВТССУМ 2007: 1360) як складник похідного утворення мовносоиіумний позначає групу людей за особливостями мовних ознак. Мовносоціумне вживання морфологічних, синтаксичних та інших форм є об’єктивним, оскільки грунтоване на спонтанній мовленнєвій стихії, яка у всіх різноманіттях може бути встановлена лише за умови аналізу усієї нескінченної множини текстів. Мовленнєва стихія постає основним законом життя особистости в мову й через мову, тому що людина «живе в колі своєї мови й вийти з неї може лише в іншу мову» (Гумбольдт 1985: 224), пор. також погляди О. Потебні (Потебня 1993: 45 і далі), М. Гайдеггера (Гайделгер 2007: 37, 42 і далі). У статті не поставлене завдання проаналізувати увесь обсяг правописних норм, особливости відбиття в них узусно мовленнєвих стихій, уплив яких постає визначальним на формування варіантности зі встановленням їхньої регулярности, продуктивности, частотности, оскільки в центрі уваги перебуває теоретичне узагальнення: 1) основних чинників формування й збереження правописних норм; 2) визначальних тенденцій тяглости прескрипцій; 3) співвідносности морфологічних та інших форм із національною пам'яттю й ідентичністю та ін.

Основними методами дослідження постають описовий (для опису встановлених і спостережуваних дискурсивно-правописних практик), актуалізаційно-інтерпретативний (осмислення кваліфікації прескрипцій в історії українського правопису), функційний (визначення призначення прескрипцій), структурний (вияв відносин між новими й новітніми мовними одиницями з окресленням їх підпорядкування прескрипціям). Джерельною базою студіювання постали матеріали сучасних лексикографічних (орфографічних) праць, мова засобів масової інформації, а також правописні практики різних років, матеріали Українського національного лінгвістичного корпусу (https:/cutt.ly/Xf9xUMU (20.02.2020)).

Правописна практика, усталення мовних норм, їхня кодифікація й послідовна стратифікація мотивовані мовносоціумними чинниками, з-поміж яких значущими постають об'єктивні виміри використання тих чи тих лексем, їхнього сполучення, функційного навантаження в різних стилях та ін. У мовній спільноті спонтанно вживані форми набувають пріоритетности через частотне домінування, ширення в різних мовно-корпоративних утвореннях, генераційних ${ }^{1}$ прошарках, освітніх формаціях, усталення в гендерних групах, а також популярністю в межах певної території та ін. Кожний із цих і подібних чинників постає значущим сам по собі, але здебільшого вони діють спільно. Мовносоціумна

\footnotetext{
${ }^{1}$ Термін генераційний (від генерайія (в сенсі - покоління)) та похідні від нього повногенераційний, частвогенерачійний та ін. використовує О. Ткаченко в соціолінгвістичній класифікації мов (Ткаченко 2005: 63-68).
} 
мотивованість вживання певного граматичного варіанта мотивована його зрозумілістю, співвідносністю з іншими рівнорядними утвореннями. Пор., наприклад, розширення функційного навантаження форми давального i/чи місцевого відмінка на -ові (-еві) іменників чоловічого роду в сучасних дискурсивно-правописних практиках, що зумовлено їх тяглістю (Загнітко 2011: 341-343), кореляцію з категорійними формами особи, поширенням такої флексії на більшу частину лексем цього зразка та ін.:

(1) За річкою, продираючись на стежку, сік ножем верболіз, стинав гілки, щуо заважали просто йти, - шукав ножеві застосування (I. Багряний);

(2) По тротуарові внизу йде малюк, штовхає коляску, яка поволі котиться перед ним (А. Дністровий)

2. Статус прескрипції: частота, функція, пріоритет. Частота словоформи в іiі інваріантному та варіантному i/чи варіантних виявах постає досить вагомим критерієм для встановлення її статусу, надання пріоритету з послідовним тлумаченням її як нормативної. Перед укладачами правопису завжди актуальними є питання: а) відповідности національної ідентичности; б) співвідносности 3 іншими типологічно спорідненими утвореннями; в) дотримання закономірностей тяглости та ін.

Сучасні правописи не відбивають активних процесів у динаміці родової диференціації іменникових лексем, що, очевидно, можна пояснити дотриманням традиції укладання таких видань. Родову належність іменників теоретично схарактеризована у відповідних граматичних описах та інтерпретаціях (Загнітко 2011: 127-157; Вихованець та ін. 2017: 105-115), а в прикладному вимірі відбита у правописних (Синявський 1929) та орфографічних (ВЗОССУЛ 2004), тлумачних (ВТССУМ 2007) словниках. Основний корпус іменників має усталену родова належність, яка грунтована на: 1) семантичній мотивації через кореляцію морфологічних значень роду зі складниками номінативної категорії статі (дідусь - бабуся, свекор - свекруха; вовк - вовчиця, лев - левиця) або номінативної категорії дорослости ↔ недорослости, де перший компонент є двохелементним (циган - цчиганка (дорослість) ↔ циганча - цчиганеня (недорослість); 2) формальній маркованости (дубө, лісю; береза, вода) та ін. Особливістю родової належности іменників $є$ іії постійне закріплення. 3-поміж незначної частини іменникових лексем наявне хитання в родовій диференціації, що активно спостережуване у слів із кінцевим м'яким приголосним основи, пор., наприклад: граділь-ө-граділя, ч. р. і граділі, ж.р., гризайль-ө-гризайлю, ч. р. і гризайлі, ж. р., жужіль-ю - жужелю, ч. р. і жужелі, ж. р., картель-ө - картелю, ч. р. і картелі, ж. р., купіль-ө - купелю, ч. р. і купелі, ж. р., лунь-ө -луня, ч. р. і рідковжив. луні, ж. р., стріхіль-ө-стріхіля, ч. р. і стріхілі, ж. р., черінь-ө-череня, ч. р. і черені, ж. р., чорнобиль-ө-чорнобилю, ч. р. і розм. чорнобилі, шашіль-ө-шамеля, ч. р. і розм. шамелі (Загнітко 2011: 156-165), пор.:

(3) Центральним у изьому блоияі був репортаж про причетність федерального міністра природних ресурсів до діяльності нелетального гірничовидобувного картелю в Астероїдному поясі (О. Авраменко); 
(4) Джерела картелі прямо говорять про те, щзо фінансова ситуація давно на ринках ускладнилася (Кореспондент.2015. 8-17.09)).

Уживання чи пріоритет відповідного варіанта словоформи мотивовані внутрішньомовним (належністю до парадигмального класу) і зовнішньомовним (мовносоціумними дискурсивними практиками) чинниками. Перший відбитий у морфологічному роді іменника, він і закріплює варіант словоформи (у наведених прикладах - перше слово), другий - здебільшого зумовлений ознаками аналогії (нульове закінчення, тяжіння до морфологічного роду слова на позначення родового поняття, синонімічного слова та ін.), пор., напр.: жужіль-ю -жужелю, ч. р. і жужелі, ж. р., купіль-ө - купелю, ч. р. і купелі, ж. р. і под. Використання відмінкових флексій цілком підпорядковане, з одного боку, граматичним прескрипціям (парадигмальний клас), a, з другого, - повністю орієнтоване й залежне від мовносоціумних пріоритетів, формуванням у таких групах цінности прескрипції (відхилення від норми, їі розхитування).

2.1. Внутрішньо- та зовнішньомовні чинники розхитування норми. I3 сучасними граматичними законами безпосередньо пов'язана правописна практика так званих невідмінюваних іменників, що виокремилися як цілісна сукупність в українській літературній мові від 20-х років XX ст.: авеню, ебосі, шимі; портьє, рантьє; міс, мадам. В останніх граматичних студіюваннях їх розглядають у межах парадигмальних класів, надаючи їм окремий статус - нульова відміна (термін належить І. Вихованцеві (Вихованець та ін. 2017: 105-115)) 3 опертям, звичайно, на відсутність формальної видозміни в лексем. Показники ж відмінків простежувані в межах щонайменшої синтагми ${ }^{2}$ (пор.: Н. в. знайоме попур $i=3$. в. знайоме попур $i=$ Кл. в. знайоме попур ${ }^{3}$; Р. в. знайомого попу$p i$; Д. в. знайомому попурі; О. в. знайомим попурi; М. в. (y) знайомому попурi):

(5) Потім викликав покоїку і звелів приготувати постіль, потім подумав і потелефонував униз до портьє (М. Білкун) - Р. в.;

(6) Твої функиії залишаються такими ж-приймеш гроші і даси четвертак портье (Ю. Винничук) - Д. в.

Інтенсивність розширення множини так званих невідмінюваних іменників очевидна, що, безперечно, становить певні трудноші в тих чи тих правописно-дискурсивних практиках, оскільки перед мовцем постає завдання впізнавання невідмінюваного іменника. До того ж низка іменникових лексем в окремих дискурсивних практиках тяжіє до відмінюваности. Підтвердженням цього постає художньо-белетристичний та інші дискурси:

(7) - Ми ніц нічо не чуємо й не бачимо без радіва й газет, хіба хтось щуось по телевізору побачить, якщио його має (Г. Тарасюк);

${ }^{2}$ Синтагма - мінімальний контекст реалізації слова i/чи словоформи. У статті під мінімальною синтагмою мається на оці стрижневе слова разом із залежним.

${ }^{3}$ В іменників - назв неістот форма кличного відмінка позбавлена семантичної мотивації, тому їі вираження $є$ цілковитою умовністю. 
(8) Наступного дня він відвозив автом свою родину і Мілену до залізниці (С. Андрухович);

(9) Я був циілком приголомшений, коли вийшов з кіна (Г. Гордасевич);

(10) Вер сиділа з Корвиним у фоє кіна, чекаючи на початок сеансу (В. Домонтович).

У (7) наявне відтворення народно-розмовної стихії з наголошенням особливостей адаптування нових слів до об'єктивних потреб спілкування, а в (8),(9), (10) - відбиття власне авторських інтенцій. Постання того чи того варіанта словоформи часто мотивоване в мовносоціумній практиці активною дією аналогії, пор. село (середн. р., відмінюваний іменник) - авто, кіно, радіо (середн. p., інваріантно невідмінювані, варіантно відмінювані за парадигмою іменникових лексем середн. р. на -o). Природнішим для української мови було б відмінювання дво- і більше складових іменників 3 кінцевим голосним -о, що стоїть після приголосного. Потрібно уточнити, що у правописі 1929 року «чужі іменники» розглянуто як такі, що «відмінюються як іменники ніякого роду слова: авто, бюро, депо, кіно, мотто, пальто, піяніно, трюмо, саго, изицеро», усі ж інші - зараховані до невідмінюваних (до слова радіо можлива словоформа радіом) (УП 1929: 48).

Зміна морфологічного роду в низки невідмінюваних іменників здебільшого зумовлена декількома причинами, з-поміж яких актуальним є закон семантико-тематичного підпорядкування: геко, тейє, тейю - ящірка; ківі, тюрко, тіному, таку, току - пташка (однорідні видові назви: ластівка, ворона, сорока, зозуля, синиия); фiфi - завитка; фугу, хромулі, івасі - риба (івасі- тихоокеанська сардина) (Загнітко 2011: 145). Перелік змін у родовій належності невідмінюваних іменників можна продовжити, оскільки в сучасній українській мові вони становлять досить розмаїтий клас слів. До них належать лексеми іншомовного походження, що здебільшого відрізняються своїм закінченням. Невідмінювані іменники в сучасній мові охоплюють загальні назви неістот із кінцевими голосними [e], [a], [o], [y], [i], пор.: пюре, абреже, леоне, адарме, аміле, бозе, медресе; фейхоа, юбеа, пагуа, па-де-труа, пульга, туранга, аймара, антика; грего, майстро, памперо, сироко, солано, памперо, торнадо; абрау, каригіну, муку, секу, кодру, мангбету, мату, тиграу; фортеп'яно, есперанто, ідо, кабалето, кавало, кавецо, касето, макао; ларі, криманчулі, кісі, ебосі, седзі, сугалатамі, мачоні, таасакраві та іменники - загальні назви істот. Останні диференційовані на дві великі групи: а) іменники - назви осіб, основа яких має кінцеві голосні [a], [o], [y], [e], [u], [i], наприклад: архара, бабуа, бакуба, бавемба, джола, дуала; ібібіо, бакомо, бамбіно, бадьоро, бороло, маестро, гого; ву, курчи-вандлу, немху, нонсу, чентсу; абаде, камікадзе, санде, базе, мушаче, маконде, протеже, рантьє, конферансьє; візаві, камбі, леді, суамі; бари, манси, маори, тахтаджи; або фінальні приголосні, пор.: волоф, уолоф, яолоф, ханум, мадам, міс, містріс, місіс, футен, джі-ей; б) іменники - назви тварин, основа яких закінчується голосними [a], [o], [y], [e], [u], [i], наприклад: аноа, арара, макао, кліо, манго (продавець), орорно, геко, калініко, иимпанзе, сайміри, соси, уакари, авачі, вашиші, гризлі, фіфрі та ін.

Клас так званих невідмінюваних іменників істотно розширюваний за умови зарахування до нього іменникових лексем із морфологічною незмінюваністю, 
зокрема 4 : 1) жіночих власних імен із кінцевим приголосним основи: Муккарам, Рузигуль, Джанет, Мерилін, Ев, Арбик, Арбинак, Аяк, Байлак, Дапар, Каллар (приблизно 3000); 2) жіночих власних іншомовних імен із кінцевим голосним основи [o], [u], [y], [e], [i]: Майсуло, Тойсуло, Янсуло, Назли, Асли, Айбану, Аксилу, Бибісилу, Гадельбану, Шелеме, Кільбіге, Ендемі, Ільбіне, Сальді, Ілебі, Бібі (пор.: $[o]-83,[u]-81,[y]-205,[e]-424,[u]-61,[i]-239)$; 3) жіночих прізвищ власне українського й іншомовного походження 3 кінцевим приголосним основи: Яремчук, Воєдчук, Коломієць, Вечір, Олехнович, Ральф; 4) жіночих прізвищ власне-українського й іншомовного походження з кінцевим голосним: Царенко, Перевесло, Грінченко, Дюма, Алаку; 5) чоловічих власних імен іншомовного походження з кінцевими голосними: [i], [e], [u], [o], [y]: Бакі, Барі, Будаві, Валі, Гані, Мінвалі, Сафаргалі, Асабе, Уразгільде, Байгільде, Буушки, Таначи, Акушти, Ябизоко, Дзабо, Баласуу, Дьокту, Сау, Даду (3-поміж досліджуваного корпусу текстів зафіксовано таких імен із кінцевими голосними відповідно: $[i]-716,[e]-$ $166,[u]-79,[o]-127) ; 6)$ чоловічих прізвищ іншомовного походження 3 кінцевими голосними [a], [i], [y], [е]: Дюма, Легуа, Руставеллі, Нонашвілі, Горшту, Думбадзе, Гонтадзе; 7) російських чоловічих прізвищ на [-аго], [-ux], [-ово]: Мертваго, Черних, Дурново, Жеваго; 8) російських географічних назв із кінцевим формантом на голосний або з елементами [-ово], [-іно], пор.: Сєдово, Применково, Пушкіно; 9) іменників - власних географічних назв, зокрема: а) міст (Токіо, Делі, Тбілісі, Манагуа), б) країн (Нікарагуа, Чилі, Перу), в) річок (Mісcісіпі, Miccypi), г) гір (Кіліманджаро); 10) назв іншомовних газет, журналів, тижневиків: «Ноє Цайт», «Таймс», «Нью-Йорк Таймс» («Нью-Йорк Таймз»), «Ненсабадтог»; 11) складноскорочених слів ініціального й ініціально-звукового зразка: $3 С У, 3 B O$,

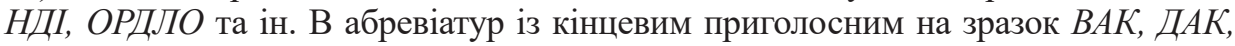
$M O H, H A H$ і под. у сучасних правописних практиках наявні тенденції їх ненормативного відмінювання за відповідним зразком іменників чол. р. II відміни:

(11) Прийшло знову повідомлення з МОНу про перегляд особливостей $3 Н О$ (День.2001.12.06);

(12) ДАКом схвалено нові положення формування разових спечіалізованих рад (Освіта.2016.2.01).

3. Об’єктивний мовносоціумний статус прескрипцій: кодифікація та стратифікація. Об'єктивний мовносоціумний статус національно-суспільних прескрипцій зорієнтований на їх повноцінне функційне навантаження в усіх сферах суспільного життя, що сприяє уніфікації, загальнотеориторіальному, міжгенераційному використанню унормованих словоформ, конструкцій, розділових знаків та ін. Водночас у сучасному узусі простежувані або хитання правописної норми, або конкурентність варіантів норми. Підтвердженням цього можна вважати правопис новоутворених складних слів разом, окремо та 3 дефісом. Остання редакція Украӥнського правопису (2019) істотно уніфікува-

\footnotetext{
${ }^{4}$ Автор не ставить на один щабель питомі жіночі форми й іноземні прізвища, оскільки вони діахронно різні. Водночас усі ці лексеми в сучасній мові належать до невідмінюваних. Їх розгляд у правописах висвітлено в аналізі різних норм. Для зручности аналізу сучасної невідмінюваности іменників їх умовно об’єднано.
} 
ла правописні норми слів із цілою низкою регулярно вживаних іншомовних компонентів на голосний та приголосний на зразок абро- 5 , авіа-, авто- ('само', 'автоматичний'), агро-, аеро-, аква-, алко-, арт-, астро-, аудіо-, біо-, боди-, боді- (перед голосним), веб-, геліо-, гео-, гідро-, дендро-, екзо-, еко-, економ-, етно-, свро-, зоо-, ізо-, кібер-, мета-, метео-, моно-, мото-, нарко-, нео-, онко-, палео-, пан-, пара-, поп-, прес-, псевдо-, соціо-, теле-, фіто-, фолк- (фольк-), фоно- та ін. із унормуванням їх правопису разом зі словом:

(13) аброморфема, авіарейс, автомаршрут, агроферма, аерознімання, аквамодель, алкотест, артринок, астрокорекція, аудіотехніка, біотехнологія, бодибілдинг, бодіарт, вебресурс, геліочентр, геополітика, гідропарк, дендромузей, екопродукт, економномер, етногурт, євростандарт, зоосад, кібербезпека, метамова, метеостанція, моновистава, мотокрос, наркобарон, неомодернїіт, онкочентр, панслов'янський, параолімпієєь, попмузика, пресконфере́нція, псевдонаука, соціотехнологія, телехроніка, фітопрепарат, фолкгурт, фолькфестиваль, фонотека (УП 2019: 48).

Зміни поширилися також на правопис лексем із першим іншомовним компонентом (УП 2019), що визначає кількісний (вищий від звичного, надто високий або слабкий, швидкий і т. ін.) вияв чого-небудь: архі-, архи-, бліц-, гіпер-, екстра-, макро-, максі-, міді-, мікро-, міні-, мульти-, нано-, полі-, преміум-, супер-, топ-, ультра-, флеш-:

(14) архімодний, архидиякон, бліцвипуск, гіпермаркет, екстраномер, макрорівень, максіодяг, мідіодяг, мікроутворення, мінідиск, мінітвір, мультиорганіка, нанотехнологія (УП 2019: 49).

До цього потрібно додати також уніфікування цілісного написання лексем iз першим іншомовним компонентом анти-, віце-, екс-, контр-, лейб-, обер-, штабс-, унтер-:

(15) антицентр, віцепрезидент, ексмодель, контраргумент, лейбгвардієиь, обермайстер, оберлейтенант, итабскапітан, унтерофіцер (УП 2019: 48-50).

Кожна з названих груп елементів має свої характерні особливості й властивості, правописне ж об'єднання мотивоване об'єктивним характером функціювання - відсутністю використання у мовносоціумній практиці перших компонентів як самостійних слів. Заявлене принципово відрізняє їх від складних лексем із дефісним написанням складників. Так, наприклад, лексема 'інтернет' (інколи використовують український аналог 'всемережжя'), якій у сучасній мові властивий високий потенціал творення похідних (у корпусі засвідчено 135 похідних лексем), має написання з дефісом:

5 У статті не поставлене завдання проаналізувати правописні зміни в написанні слів із першим іншомовним компонентом, тому що це окрема проблема. Активне поповнення лексичного складу української мови словами з такими й подібними компонентами вимагає щоденного вирішення питань їхнього правопису. Схарактеризована загальна тенденція до уніфікації правописної норми. 
(16) інтернет-анкетування, інтернет-банк, інтернет-видання, інтернет-виставка, інтернет-газета, інтернет-эуурнал, інтернет-інтерв 'ю, інтернет-інформація, інтернет-конференція, інтернет-магазин, інтернет-модель, інтернет-новини, інтернет-опитування, інтернет-радіо, інтернет-реклама, інтернет-спостереження (СУМ 20,6: 563-571) та ін.

4. Тяглість дискурсивно-правописних практик: еволюція й сучасний зріз. Збереження тяглости функційного статусу прескрипцій зі встановленням їхнього кількісного та якісного регулятивного використання та інституційного усталення постає однією з реалізацій мовносоціумної об'єктивної практики. Українська правописна практика у своїй історії мала різні періоди активности i/чи пасивности поширення й усталення мовних норм у загальнонаціональному просторі.

Виділення чотирьох періодів в еволюції української правописної моделі: 1) XI-XVI ст.; 2) XVI-XVII ст.; 3) XVII - початок XIX ст.; 4) перша чверть XIX ст. - до сьогодні $є$ цілком мотивованим. Кожний із виділених часових зрізів розвитку правописної практики має внутрішнє диференціювання, визначуване різними чинниками сприяння i/чи перепон у природному поширенні мовних норм, набуття ними загальнонаціонального характеру, охоплення усіх генерацій, суспільних груп. Так, наприклад, попри численні заборони українського слова, його повноцінного функційного навантаження у третьому періоді активним поставало формування графічних і правописних систем, ініційоване майстрами художнього слова (Т. Шевченко, П. Куліш (Даниленко 2012: 37-39; Срмоленко 2018)), мислителями, громадськими діячами (М. Драгоманов (Німчук 2002)), а в четвертому - можна виділити роки загальнонаціонального утвердження правописних норм (кінець 10-их - початок 30-их років), період повноцінного поновлення функційного статусу граматичних форм, їх адекватного відродження (кінець XX - початок XXI ст.). Четвертий період для української мови, ііі правописних практик сповнений трагізму, великих випробувань, поскрибування цілих шарів лексичних і граматичних норм, стилістичних традицій та ін.

Яскравим прикладом силового втручання у природний розвиток граматичного ладу стало вилучення 3 нормативного ужитку на початку 30 -х років XX ст. низки морфологічних форм (УП 1933), що було наслідком видалення 3 попереднього правопису усіх тих форм, які кваліфікували як національно оріснтовані й національно мотивовані. Підтвердженням цього постає те, що правопис 1928 року (ухвалено в 1927 р. на Всеукраїнській правописній конференції, а затверджено 6.09.1928 народним комісаром освіти М. Скрипником) наголошував: «-и мають <..>6 іменники жіночого роду III відм. на -ть за другим приголосним: від радости, з вісти, до смерти, без чверти...» (УП 1929: 35)), встановлював повноцінне функціювання форм кличного відмінка та багато іншого. Такий підхід був сприйнятий як відхід від орієнтування на російську мову, як «шкідництво на мовному фронті» (А. Хвиля (1933: 43)), тому український правопис 1933 року та наступні (1938 (Грунський 1938), 1940 (Грунський 1940), 1945 (Кириченко 1945), 1946 (Булаховський 1946), 1960 (УП 1960)) редакції (аж

\footnotetext{
${ }_{6}^{6}$ Знак <..> використано на позначення пропуску певного тексту.
} 
до «Український правопис: проєкт» (1999)) вилучали такого зразка норми (пор., наприклад, розмивання форм кличного відмінка іменників, форм родового відмінка на зразок крови, любови іменників III відміни, форм давноминулого часу, принципова зміна правопису слів іншомовного походження та ін.). В останній період розвитку українського правопису наявні часи всенародного єднання, охоплення єдиними правописними нормами всіх українських земель (20-ті роки XX ст.), і часи репресивно-обмежувальних заборон ${ }^{7}$, силових втручань у природну стихію розвитку української мови (Ю. Шевельов (1988)), і часи активного національно-свідомого відродження, переосмислення усталених правописних практик, усвідомлення їх статусу в самоідентифікації українців та ін. Особливо важливим $є$ те, що на початку XXI ст. активізувалася тенденція до збереження тяглости правописної традиції, повернення в активне використання національно-мотивованих форм родового відмінка однини іменників III відміни жіночого роду на - ть після приголосного, а також слів кров, любов, осінь, ciль, Русь, Білорусь (УП 2019: 128-129) з актуалізованою флексією - и (пор. нормативний статус закінчення - $и$ для таких іменників в українському правописному дискурсі 20-х років (УП 1926: 41; УП 1928: 37; УП 1929: 35), якій надано статус синонімічної поряд із флексією - $i$ (УП 2019: 128-129):

(17) гідности, незалежности, радости, смерти, чести, хоробрости; крови, любови, осени, соли, Руси, Білоруси ↔ гідності, незалежності, радості, смерті, честі, хоробрості; крові, любові, осені, солі, Русі, Білорусі $i$ (УП 2019: 128-129).

Одним 3 аргументів збереження тяглости функційного статусу прескрипцій родового відмінка іменників III відміни жіночого роду на $-m b$, а також слів кров, любов, осінь, сіль, Русь, Білорусь із флексією - и постає використання такої форми в об'єктивній правописній практиці 20-30-их років ХХ ст., їі кодифікація в художньо-белетристичному, публіцистичному та інших дискурсах української діаспори, іiї використання у спонтанних мовленнєвих практиках кінця XX - початку XXI ст. та ін. Повноцінного повернення флексії $-u$ родового відмінка іменників жіночого роду III відміни не відбулося (пор., напр., п. 46 § 25: «-и мають <..> усі речівники жіночого роду на приголосний (див. § 22 III відміна): з радости, без подорожи, до ночи, від розкоши, крови, твари, молоди, паморози, соли, тіни, Роси, артіли, морали, матери» УП 1926: 41)). Її відсутність у численних художніх та інших текстах митців 20-30-их років, що перевидавалися в 40-80-і роки - аж до упровадження нової редакції українського правопису (УП 2019), мотивована редакторською коректурою. Таким чином свідомо фор-

${ }^{7}$ Репресивно-обмежувальні, силові та інші втручання у природний розвиток української мови охоплюють різного плану цілеспрямовані руйнівні засоби - від російщення до вилучення тих чи тих морфологічних форм, синтаксичних конструкцій, лексичних засобів та ін., а також нищення національно-свідомої еліти із чітко окресленою метою зміни іiі органічної будови, руйнування поступової еволюції, переміщення ії комунікативної сили на маргінеси, що сукупно переслідувало реалізацію основної настанови - формування «радянського народу». Заявленій меті була підпорядкована на початку $30-$ х років XX ст. суцільна кирилізація мов радянської імперії (пор. зміну в цей час українського правопису (УП 1928, УП 1929, УП 1933)). 
мувався розрив у правописній традиції, розхитування іiї цілісности, пор., наприклад, видання творів митців художнього слова, публіцистики у 20-і роки в Україні та протягом XX - XXI ст. у США, Канаді та ін.: Г. Косинки (махлаюватости і вбогости (Косинка 1926) / махлаюватості і вбогості (Фавст; Косинка 2009)), Т. Осьмачки (опам'ятавшися від иієї безпосередности (Осьмачка 1951) $\rightarrow$ опам'ятавиися від иүієї безпосередності (План до двору; Осьмачка 2002)), В. Підмогильного (він несвідомо шукав споріднености (Підмогильний 1928) / він несвідомо шукав спорідненості (Місто; Підмогильний 2014)), (дійшло до свідомости (Багряний 1950) / дійшло до свідомості (Багряний 1950)), У. Самчука (иим самим уникнути, безпосердньости (Сумчук 1947) / изим самим уникнути, безпосердньості (Сумчук 1947))та ін. Дискурсивна практика «скрипниківського» правопису зберегла свою повноцінність в українській освіті (Ковалів 1977), періодиці, художніх творах, численних перекладах у Великій Британії, Канаді, США, Німеччині, Австралії і под., пор. художньо-белетристичну, публіцистичну та інші практики журналів «МУР», «Трембіта», «Цвіркун», «Сучасність», «Українець», а також видання творів І. Багряного, У. Самчука, переклади ${ }^{8}$ Біблії I. Огієнком, опубліковані в Німеччині, Бельгії, США та ін.:

(18) Брати сіли - військові з виразом незалежности й своєї професійної гідности (I. Багряний (Багряний 1950));

(19) А ввесь народ бачив цуе, $і$ закричали вони з радости, та й попадали на обличчя свої (Біблія, перекл. І. Огієнка);

(20) Право життя і право смерти (У. Самчук (Самчук 1947)).

Кінець XX ст. - початок XXI ст. є особливим з погляду збереження тяглости функційного статусу прескрипцій родового відмінка іменників III відміни жіночого роду на -mь після приголосного, а також слів кров, любов, осінь, сіль, Русь, Білорусь із флексією - $и$ в новій редакції правопису (УП 2019: 127-128), оскільки в цей час у більшости випадків автори самостійно надавали пріоритет тому чи тому варіанту, що здебільшого стосувалося художньо-белетристичних дискурсивних практик, публіцистичного дискурсу, де сила редакторського впливу мінімізувалася:

(21) Народ-бо вже пройнявся таким духом, щуо несподівано відкрив, відчув містику химерної дійсності, - бо жадоба крови стала реальністю (О. Ульяненко);

(22) Наснажений патріотизмом, талановитий поет намагається у свойому творі викликати в князів і слухачів гаряче почуття любови до «Землі Русичів» $і$ зрозуміння потреб спільної боротьби перед наступом ворожого Степу (В. Чемерис);

(23) Одначе Емілія була справжнім зразком хоробрости, бо ані не думала втрачати зимну кров $i$, підібравщи на березі бамбукову тичку, побігла (Ю. Винничук).

\footnotetext{
${ }^{8}$ Переклади Святого Письма вимагають особливої уваги, їх потрібно розглядати осібно. Водночас практика використання тих чи тих морфологічних форм, синтаксичних конструкцій та ін. у таких перекладах засвідчують їх високий ступінь кодифікації.
} 
Аналізовані форми містять у своєму вияві пам'ять минулих років і водночас відбивають у звучанні народно-розмовну стихію, що свідчить про їх двохвекторну дискурсивно-правописну практику. Двохвекторність таких форм підтверджувана, з одного боку, активним виявом в українських говорах (див. Атлас української мови (1984 - 2001)), з другого, збереженням їх використання в мовних практиках української діаспори, наявним відроджувальним потенціалом самих морфологічних форм, обтяжених національною пам'яттю і под. Повернення аналізованих національно-мовних форм відбулося в Україні через 86 років (вилучення (УП 1933) і фіксування (УП 2019)), певною мірою, засвідчило їх перервність у мовних генераціях (сформувалося декілька поколінь, яким безальтернативно пропонувалося використовувати лише закінчення $-i)$. Загалом питання про функційне навантаження флексій $-u$ та $-i$ форм родового відмінка однини іменників жіночого роду III відміни гостро дискутувалося під час обговорення проєкту українського правопису в 1999 році, згодом розглядалося науковцями з опертям на «Атлас української мови» (Німчук 2002; Тараненко 2005: 85-104; 2008: 159-189), обговорювалося на різних форумах (Про закінчення 2013-2014), ставало предметом розмови в засобах масової інформації. Штучне нагнітання несприйняття таких і подібних змін мовним соціумом стало на перешкоді схвалення заявленого проєкту (УП 1999) як нормативного й загальнонаціонального та водночас напрацювання іншого проєкту (Русанівський 1999). Обидва проєкти залишилися в такому статусі без подальшого затвердження.

\section{5. Основні завдання об' сктивних дискурсивно-правописних практик.} Нормативно-кодифікована правописна практика одним з основних завдань передбачає максимальну реалізацію об’єктивних параметрів нормативних тенденцій у синхронному вимірі. До таких тенденцій можна віднести в українському правописному дискурсі множину флексій родового відмінка іменників чоловічого роду II відміни. Констатована множина охоплює використання закінчень $-a(я)$ та $-y(ю)$, функційний діапазон яких постає нерівнорядним (УП 2019: 112-118). У зв'язку з тим, що в об'єктивному просторі мовних практик наявне розширення функцій флексії-y(ю), зокрема в тематичних групах 'найменування населених пунктів', ‘назви річок', 'назви долин’ та ін., у новій редакції українського правопису (УП 2019) закріплене закінчення $-a(я)$ лише в «назвах населених пунктів із суфіксами -ськ-, -цьк-, -ець-, з елементами на зразок -бург-, -град- (-город-), -піль- (-поль-), -мир, -слав-:

(24) Бердянська, Луизька, Бобриния, Кременияя, Трускавия, Піттсбурга, Вишгорода, Миргорода, Шаргорода, Борисполя, Тернополя, Ямполя, Житомира, Ярослава (УП 2019: 112-113),

а також у назвах річок, населених пунктів і географічних назвах з наголосом у родовому відмінку на кінцевому складі та із суфіксами присвійности -ів- (-їв-), -ев- (-св-), -ов-, -ин- (-ін-), -ач-, -ич-: 
(25) Бика, Дніпра, Дністра, Збруча, Псла, Тетерева; Вільхівия, Діния, Інгульия, Тория, Хустия; Олеськова, Львова, Харкова, Києва, Колгуєва, Харкова, Ходорова, Батурина, Пирятина, Святошина, Снятина; Бахмача, Гадяча, Галича (УП 2019: 112-113),

лише в окремих випадках з наголосом на корені іменника: Бреча, Вовка, Довжика, Малого Куяльника, Салгира, Свіжа, Смотрича» (УП 2019: 112).

У різних дискурсах (науковому, публіцистичному та ін.) використання флексій $-a(я)$ та $-y(ю)$ в родовому відмінку іменників чоловічого роду II відміни постає дискусійним, що підтверджують численні пропозиції, які надходили до Правописної комісії в період її роботи (2014-2019). І сьогодні дописувачі пропонують свої моделі уніфікації цих форм щодо використання флексій - $а(я)$ та $-y(ю)$. Відомо, що особливим статусом у збереженні об'єктивних параметрів нормативних тенденцій у синхронії має використання словоформ у дискурсивній практиці представників інтелектуальної, моральної, політичної та інших сфер суспільства. Відбиттям цього $є$ збереження співвідносности флексій $-a(я)$ та $-y(ю)$ в дискурсивних практиках представників інтелектуальної сфери, зокрема в оригінальних текстах І. Багряного, В. Домонтовича, У Самчука, Ю. Шевельова та ін. (див., наприклад, корпуси текстів Юрія Шевельова (https:// cutt.ly/QghD7DI), Михайла Коцюбинського (https://cutt.ly/fghFthI)). У таких текстах відбита граматична правописна норма 20 -их років, за якою в родовому відмінку «іменників-назв місцевостей, країн, річок, міст <..> вживається то $<. .>$-y, -ю (далеко частіше), то <..> -a, -я: <..> Берліну, Лондону, Парижу, Риму, Нью-Йорку, Херсону» (УП 1928: 34-35). Використання таких форм у художньому дискурсі кінця XX - початку XXI ст. мотивоване орієнтуванням на правописну практику 20-х років, пор.:

(26) Вони самі годуються при тому каламутною, сумнівної якости ідеологічною рідиною, видаючи - безпомічні еклектики - галасливі заяви лівобуржуазного снобізму Парижу й Берліну про технічний індустріяльний стиль за остаточні гасла пролетарської доктрини (В Домонтович),

i

(27) Ну чого всі думають, щио як панківська дурнувата зачіска - то конче з Амстердаму? (І. Карпа);

(28) Така стара прелюдія жаги: Дахи Парижу, очі барвінкові. Блиск Ренуара - фарби береги Всього за крок до справжньої любові (Т. Андрушко).

Використання словоформи i/чи словоформ представником (i/чи представниками) відповідної інтелектуальної сфери часто відіграє істотну роль у іiі активізації, набутті статусу регулярної, узусної, що сприяє збільшенню ії кількісно-частотного вияву, функційного навантаження. Поєднання декількох чинників посилює нормалізацію словоформи, іiі кодифікацію. 
6. Іституалізація дискурсивно-правописних практик. Сучасні правописні практики зорієнтовані на об'єднання різних стихій стандартизації й кодифікації тих чи тих графем, сполук слів, морфологічних і синтаксичних форм. Заявлені стихії об'єднують: а) суспільно-нормативні закономірності; б) функційно-прагматичні тенденції; в) дискурсивно-комунікативні норми.

Суспільно-нормативні закономірності відбиті, наприклад, у постійній динаміці прескрипцій використання великої букви. Останнє охоплює графемне виділення окремих адміністративних органів, відображенні їхніх інституційних статусів (написання найменувань органів влади: Кабінет Міністрів України, Президент Украӥни, Верховний Суд Украӥни, Конституційний Суд Украӥни та ін.), імен (Андрій, Ольга та ін.), вирізнення географічних і територіальних назв (Європа, Північна Америка і под.) та ін. (УП 2019: 70-93).

Функційно-прагматичні тенденції акумульовані в інституціюванні тих i/чи тих відзнак (орденів, медалей, премій та ін.: орден Держави, орден Свободи, Національна премія імені Тераса Шевченка і т. ін.) і под. (УП 2019: 88). Сюди ж належить формальне вирізнення значущих величин у написанні документів, пам'яток історії та культури, творів літератури й мистецтва, друкованих органів (епоха Бароко, роман «Меч Арея», автомобіль «Таврія», иукерки «Червоний мак» і под.) (УП 2019: 81). Актуалізація в сучасних суспільних запитах конфесійного дискурсу мотивувала інституалізаційну кодифікацію великої букви у словах Бог, Аллах, а також імен Бога: Сгова, Саваоф, Адонай, Елохім, імен богів і богинь у різних народів: Деметра, Вішну, Геба, Брахма, Марс, Перун, Даждьбог. До цієї групи належить і написання імен засновників релігій або окремих течій в них: Будда, Заратустра (Заратуштра), Магомет; апостолів, пророків, святих у християнстві: Іван Хреститель, Іван Богослов, Микола Чудотворецьь, Андрій Первозваний (УП 2019: 74-75). Перервність у використанні великої букви в написанні таких і похідних слів і словосполук відбилася в численних редакторсько-коректорських інтерпретаціях текстів класиків української культури та використанні малої літери в написанні слів на зразок бог $\rightarrow$ $\boldsymbol{Б}$ ог, господь $\rightarrow$ Господь, всевишній $\rightarrow$ Всевишній (Т. Шевченка (1988 і 2017), С. Руданського та ін.):

(29) Нескверними устами помолимось Богу (Т. Шевченко (2017)) і (30) Нескверними устами помолимось богу (Т. Шевченко (1988));

(31) Любітеся, брати мої, / Українулюбіте / Іза неї, безталанну, Господа моліте (Т. Шевченко (2017)) і (32) Любітеся, брати мої, / Україну любіте / I за неї, безталанну, господа моліте (Т. Шевченко (1988)).

Використання текстів, опублікованих у 30-80-і роки, й сьогодні впливає на когнітивне сприйняття правопису аналізованих лексем, що показово в цитуванні авторів минулого та аргументація вживання малої літери з наголошенням «Так в оригіналі» (25.09.2020; виступ на захисті докторської дисертації).

Функційно-прагматичні чинники охоплюють також графему великої букви i в найменуваннях ввічливости у звертаннях до однієї конкретної особи в листах, офіційних документах та ін.: Повідомляємо Вам..., Вітаємо Вас..., у відповідь на Ваш запит...; формальному вирізненні високого статусу особи i/чи осіб зразка Високі Договірні Сторони, Надзвичайний і Повноважний Посол (в актах 
міжнародного значення, у дипломатичних документах), Автор, Видавництвво (в авторському договорі), Замовник, Виконавецьь (в угодах) і т. ін. (УП 2019: 89).

До дискурсивно-комунікативних норм належить стихія стандартизації відповідних маркерів графічних скорочень та ін. ( $Б$ - байт, $B$ - ват, $a в m$. - автор, акад. - академік, арк. - аркуш, м. - місто, смm. - селище міського типу і под.), адекватне прочитання яких можливе лише у відповідних дискурсивних практиках. Збільшення кількости такого зразка графічних скорочень мотивоване їх інституційним статусом, законом мовної економії (УП 2019: 90-91),

7. Об'сктивна мотивованість пунткуаційно-правописних приписів: статус авторських інтенцій. Спрямування на кумулятивне відбиття нормативних тенденцій використання форм, конструкцій повноцінно зреалізовані в динаміці статусу й застосування формально-граматичного (структурного), семантичного (структурно-семантичного), інтонаційно-ритмового виявів принципів сучасної пунктуації, а також - у формуванні особливої площини реалізації функційно-стилістичного ( $\rightarrow$ функційно-авторського) принципу пунктуації (пор. (Савченко 2012: 152-155)), ніяк не унормованого й пізнаваного лише в межах авторських текстів:

(33) I - знову я один тривожу душу (Т. Андрушко);

(34) Смуток нащзадків - як танец̧ь бджоли, танец̧ь бджоли на безсмертному полі (Л. Костенко);

(35) Тоді - вкривайтеся пилом, струни (О. Олесь); (32) Німим - піснями заливатись (О. Олесь);

(36) На иибках - зимовий мережок, зірчасто-білий візерунок (В. ЕлланБлакитний);

(37) I - кинув хтось мені квітку (О. Олесь);

(38) А щуе - спасибі вам за все (Л. Костенко);

(39) Але - близька вже довгождана путь По пралісах, по долах і по горах (О. Ольжич).

У сучасному правописному просторі помітним постає істотне розширення довжини речення, утворення перехідних величин між реченням і текстом, коли наддовге речення $є$ надзвичайно ускладненим (прозові дискурси О. Забужко (Забужко 2015), О. Ульяненка (Ульяненко 2013), В. Медвідя (Медвідь 2006) та ін. (пор. студіювання функційного навантаження наддовгих речень у художньому дискурсі (Загнітко 2011: 701-721)), посилення навантаження функційно-стилістичного (функційно-авторського) принципу пунктуації. У таких похідних реченнєвих утвореннях часто реалізуються різні рівні інтродукції - першого, другого, третього, четвертого, п’ятого, шостого рівнів, що зумовлює відповідне ускладнення їхнього пунктуаційного малюнка. У наддовгих реченнях одне вставлення вмонтовується в інше і т. ін, (Загнітко 2011: 730). Не менш значущим є розширення функційного тла тире в порівнянні, двокрапки, крапки з комою та ін. (див. ілюстрації (33), (34), (35), (36), (37), (38), (39)). Пунктуаційна граматика сучасної мови вимагає окремого студіювання (Загнітко 2012: 134 140), оскільки зміни в структуруванні речень, збільшення кількості інформації 
в них визначають переформатування використання розділових знаків. Новітні процеси в українській пунктуації, належно відбиті в новій редакції правопису (УП 2019: 196-256), відображають їі розвиток з орієнтуванням на ускладнення письмового мовлення з реалізацією в ньому прагнення в одній реченнєвій структурі передати максимальний обсяг інформації, відтворити об’ єктивний напрям розвитку авторської думки з відступами, уточненнями, деталізаціями, поглибленнями, ускладненнями та ін.

8. Висновки й перспективи. Грунтовний розгляд мовносоціумної об'єктивно-дискурсивної мотивованости прескрипцій свідчить про функційне навантаження низки чинників у їхній динаміці. Особливий статус належить збереженню тяглости функційного статусу прескрипцій з виявом їхнього регулятивно-інституційного використання, а також обгрунтування об'єктивного мовносоціумного статусу національно-суспільних прескрипцій 3 кумулятивним відбиттям нормативних тенденцій використання форм, конструкцій у відповідних нормативних практиках. Вирішальним чинником динаміки мовної норми, ïi стратифікації постають об’єктивні параметри нормативних тенденцій у синхронному вимірі, статус тих чи тих прескрипцій в об'єктивній практиці, часовий зріз мовної норми, їі тривалість.

Перспективним є суцільне обстеження максимально широкого корпусу текстів 3 репрезентативними дискурсивними практиками для формування цілісної картини правописних норм у відповідні періоди розвитку української мови, їх функціювання з простеженням вилучення морфологічних, синтаксичних форм, стилістичних норм та ін. як реалізації цілеспрямованої політики русифікації, нищення всього національно-питомого, а також встановлення співвідносности динаміки правописної норми (i/чи правописних норм) з граматичними описами, статусом правописних норм у лексикографічних працях.

\section{Використана література}

Атлас української мови: В 3-х т. Київ: Наукова думка, 1984 - 2001.

[Atlas ukrainskoi movy: V 3-kh t. Kyiv: Naukova dumka, 1984 - 2001]

Булаховський, Леонід А. (ред.) Український правопис. Київ: Українське державне видавництво, 1946.

[Bulakhovskyi, Leonid A. (red.) Ukrainskyi pravopys. Kyiv: Ukrainske derzhavne vydavnytstvo, 1946]

Вакуленко, С. «Загальні тенденції в унормуванні української мови (1920-2015 pp.)». [В:] С. Вакуленко, К. Каруник (ред.) Українська мова: унормування, розунормування, перевнормування. Харків: Харківське історико-філологічне товариство, 2018, 7-259.

[Vakulenko, S. «Zahalni tendentsii v unormuvanni ukrainskoi movy (1920-2015 rr.)». [V:] S. Vakulenko, K. Karunyk (red.) Ukrainska mova: unormuvannia, rozunormuvannia, perevnormuvannia. Kharkiv: Kharkivske istoryko-filolohichne tovarystvo, 2018, 7-259]

ВЗОССУЛ: Великий зведений орфографічний словник сучасної української лексики. Київ; Ірпінь: ВТФ «Перун», 2004. 
[Velykyi zvedenyi orfohrafichnyi slovnyk suchasnoi ukrainskoi leksyky. Kyiv; Irpin: VTF «Perun», 2004]

ВТССУМ: Великий тлумачний словник сучасної української мови. Київ; Ірпінь; ВТФ «Перун», 2007.

[Velykyi tlumachnyi slovnyk suchasnoi ukrainskoi movy. Kyiv; Irpin; VTF «Perun», 2007]

Вихованець, Іван, Катерина Городенська. Теоретична морфологія української мови: Академічна граматика української мови. Київ: Унів. вид-во „Пульсари”, 2004.

[Vykhovanets, Ivan, Kateryna Horodenska. Teoretychna morfolohiia ukrainskoi movy: Akademichna hramatyka ukrainskoi movy. Kyiv: Univ. vyd-vo „Pulsary”, 2004]

Вихованець, Іван, Катерина Городенська, Анатолій Загнітко, Світлана Соколова. Граматика сучасної української літературної мови. Морфологія. Київ: Видавничий дім Дмитра Бураго, 2017.

[Vykhovanets, Ivan, Kateryna Horodenska, Anatolii Zahnitko, Svitlana Sokolova. Hramatyka suchasnoi ukrainskoi literaturnoi movy. Morfolohiia. Kyiv: Vydavnychyi dim Dmytra Buraho, 2017]

Гайдегтер, Мартін. Дорогою до мови. Львів: Літопис, 2007.

[Haidegger, Martin. Dorohoiu do movy. Lviv: Litopys, 2007].

Голоскевич, Григорій. Правописний словник (за нормами УКРАЇНСЬКОГО ПРАВОПИСУ Всеукраїнської Академії Наук). Харків, 1929.

[Holoskevych, Hryhorii. Pravopysnyi slovnyk (za normamy UKRAINSKOHO PRAVOPYSU Vseukrainskoi Akademii Nauk). Kharkiv, 1929]

Грунський, Микола К. (ред.) Український правопис (проект видання четвертого). Київ: Радянська школа, 1938.

[Hrunskyi, Mykola K. (red.) Ukrainskyi pravopys (proekt vydannia chetvertoho). Kyiv: Radianska shkola, 1938]

Грунський, Микола К. (ред.) Український правопис (проект видання четвертого). Київ: Радянська школа, 1940.

[Hrunskyi, Mykola K. (red.) Ukrainskyi pravopys (proekt vydannia chetvertoho). Kyiv: Radianska shkola, 1940]

Грушевський, Михайло. До управильнення українського правопису. [B:] Літературно-Науковий Вістник. 1926. Т. 89. Кн. 3, 272-276.

[Hrushevskyi, Mykhailo. Do upravylnennia ukrainskoho pravopysu. [V:] LiteraturnoNaukovyi Vistnyk. 1926. T. 89. Kn. 3, 272-276]

Гузар, Олена. Правописна комісія НТШ і питання уніфікації єдиного українського правопису на зламі XIX-XX століть. [B:] Український правопис та реалії сьогодення: Матеріали засідань Мовознавчої комісії та Комісії всесвітньої літератури НТШ у Львові 1994-1995 рр. Львів: Наукове Товариство ім. Шевченка, 1996, 12-21.

[Huzar, Olena. Pravopysna komisiia NTSh i pytannia unifikatsii yedynoho ukrainskoho pravopysu na zlami XIX-XX stolit. [V:] Ukrainskyi pravopys ta realii sohodennia: Materialy zasidan Movoznavchoi komisii ta Komisii vsesvitnoi literatury NTSh u Lvovi 1994-1995 rr. Lviv: Naukove Tovarystvo im. Shevchenka, 1996, 12-21]

Гумбольдт, Вильгельм фон. Язык и философия культуры. Москва: Прогресс, 1985.

[Gumbol'dt, il'gel'm fon. Âzyk i filosofiâ kul'tury. Moskva: Progress, 1985]

Даниленко, Андрій. ««Пиши як мовиш...», або чому Пантелеймон Куліш не став творцем сучасного українського правопису». [В:] Мовознавство. 2012. № 4, 37-54. 
[Danylenko, Andrii. «Pyshy yak movysh», abo chomu Panteleimon Kulish ne stav tvortsem suchasnoho ukrainskoho pravopysu. [V:] Movoznavstvo. 2012. № 4, 37-54]

Єрмоленко, Світлана. «Слово Т. Шевченка vs слово П. Куліша: джерела національної ідентичності». [В:] Українська мова. 2019. 4, 3-14.

[Yermolenko, Svitlana. «Slovo T. Shevchenka vs slovo P. Kulisha: dzherela natsionalnoi identychnosti». [V:] Ukrainska mova. 2019. 4, 3-14]

Загнітко, Анатолій. Теоретична граматика сучасної української мови. Морфологія. Синтаксис. Донецьк: ТОВ «ВКФ «БАО», 2011.

[Zahnitko, Anatolii. Teoretychna hramatyka suchasnoi ukrainskoi movy. Morfolohiia. Syntaksys. Donetsk: TOV «VKF «BAO», 2011]

Загнітко, Анатолій. «Пунктуаційна поетика: форми, семантика, функції». [В:] Українське мовознавство. 2012. Вип. 42/1, 134-140.

[Zahnitko, Anatolii. «Punktuatsiina poetyka: formy, semantyka, funktsii». [V:] Ukrainske movoznavstvo. 2012. Vyp. 42/1, 134-140]

Загнітко, Анатолій. Мовний простір граматики. Вінниця: ТОВ «ТВОРИ», 2018.

[Zahnitko, Anatolii. Movnyi prostir hramatyky. Vinnytsia: TOV «TVORY», 2018]

Історія українського правопису XVI-XX століття: Хрестоматія / Упорядн.: Василь Німчук, Наталія Пуряєва. Київ: Наукова думка, 2004.

[Istoriia ukrainskoho pravopysu XVI-XX stolittia: Khrestomatiia / Uporiadn.: Vasyl Nimchuk, Nataliia Puriaieva. Kyiv: Naukova dumka, 2004]

Кириченко, Ілля М. (ред.) Український правопис. Київ: Українське державне видавництво, 1945.

[Kyrychenko, Illia M. (red.) Ukrainskyi pravopys. Kyiv: Ukrainske derzhavne vydavnytstvo, 1945]

Ковалів, Пантелеймон. Український правопис. Нью-Йорк: Інститут української мови, 1977.

[Kovaliv, Panteleimon. Ukrainskyi pravopys. Niu-York: Instytut ukrainskoi movy, 1977]

Кревецький, Іван(а). «Оден правопис, передовсім у Галичині». [В:] Нова Зоря. 1929. 1 груд. (ч. 89).

[Krevetskyi, Ivan. «Oden pravopys, peredovsim u Halychyni». [V:] Nova Zoria. 1929. 1 hrud. (ch. 89)]

Кревецький, Іван(б). «Правописний хаос в Галичині та небезпека його збільшення». [В:] Нова Зоря. 1929. 21 листоп. (ч. 86).

[Krevetskyi, Ivan(b). «Pravopysnyi khaos v Halychyni ta nebezpeka yoho zbilshennia». [V:] Nova Zoria. 1929. 21 lystop. (ch. 86).]

Крижановська, Ольга. «Давноминулий час в українській мові: статус, особливості функціонування». [В:] Наукові записки Кіровоградського державного університету. Серія: Філологічні науки. 2008. Вип. 80, 143-147.

[Kryzhanovska, Olha. «Davnomynulyi chas v ukrainskii movi: status, osoblyvosti funktsionuvannia». [V:] Naukovi zapysky Kirovohradskoho derzhavnoho universytetu. Seriia: Filolohichni nauky. 2008. Vyp. 80, 143-147]

Луців, Лука. «Мовні дивогляди: клопіт з іканням». [В:] Літературно-науковий вістник. 1931. Т. 107. Кн. 12, 1089-1093.

[Lutsiv, Luka. «Movni dyvohliady: klopit z ikanniam». [V:] Literaturno-naukovyi vistnyk. 1931. T. 107. Kn. 12, 1089-1093]

Мацько, Любов. «Мовна особистість Тараса Шевченка як чинник формуван- 
ня національної ідентичності». [В:] Наукові записки Національного університету «Острозька академія». Серія «Філологічна». 2014. Вип. 50, 8-15.

[Matsko, Liubov. «Movna osobystist Tarasa Shevchenka yak chynnyk formuvannia natsionalnoi identychnosti». [V:] Naukovi zapysky Natsionalnoho universytetu «Ostrozka akademiia». Seriia «Filolohichna». 2014. Vyp. 50, 8-15.]

Найголовніші правила українського правопису. Київ: Державне видавництво, 1921.

[Naiholovnishi pravyla ukrainskoho pravopysu. Kyiv: Derzhavne vydavnytstvo, 1921]

Найголовніші правила українського правопису. Нове вид. Київ: «Червоний шлях»-УАН, 1925.

[Naiholovnishi pravyla ukrainskoho pravopysu. Nove vyd. Kyiv: «Chervonyi shliakh» -UAN, 1925]

Німчук, Василь. Проблеми українського правопису XX - початку XXI ст. ст. Київ: НАН України, Інститут української мови, 2002.

[Nimchuk, Vasyl. Problemy ukrainskoho pravopysu XX - pochatku XXI st. st. Kyiv: NAN Ukrainy, Instytut ukrainskoi movy, 2002]

Огієнко, Іван. «Рідна традиція і мова. Про правопис і вимову чужих слів». [В:] Діло. 1925. 3 лип. (ч. 145); 4 лип. (ч. 146). 5 лип. (ч. 147); 7 лип. (ч. 148).

[Ohiienko, Ivan. «Ridna tradytsiia i mova. Pro pravopys i vymovu chuzhykh sliv». [V:] Dilo. 1925. 3 lyp. (ch. 145); 4 lyp. (ch. 146). 5 lyp. (ch. 147); 7 lyp. (ch. 148)]

Огієнко, Іван. «Чистота й правильність української мови (Відповідь нефаховому критикові)». [В:] Нова Зоря. 1933. 12 лют. (ч. 10).

[Ohiienko, Ivan. «Chystota y pravylnist ukrainskoi movy (Vidpovid nefakhovomu krytykovi)». [V:] Nova Zoria. 1933. 12 liut. (ch. 10)]

Палюх, Ольга. «Правописні дебати у галицькій періодиці 20-х - початку 30-х pp. ХX ст.». [В:] Збірник праць Науково-дослідного інституту пресознавства. 2014. Вип. 4, 205-239 (https://cutt.ly/IfMEOAh (20.03.2020)).

[Paliukh, Olha. «Pravopysni debaty u halytskii periodytsi 20-kh - pochatku 30-kh rr. KhKh st.». [V:] Zbirnyk prats Naukovo-doslidnoho instytutu presoznavstva. 2014. Vyp. 4, 205-239]

Потебня, Александр. Мысль и язык. Киев: СИНТО, 1993.

[Potebnya, Aleksandr. Mysl' i yazyk. Kiev: SINTO, 1993]

Правописні правила, приняті Науковим товариством імени Шевченка у Львові. Львів: Друкарня Наукового товариства ім. Шевченка, 1922.

[Pravopysni pravyla, pryniati Naukovym tovarystvom imeny Shevchenka u Lvovi. Lviv: Drukarnia Naukovoho tovarystva im. Shevchenka, 1922]

Про закінчення родового відмінка іменників III відміни. URL: https:/cutt. ly/6ghABct (12.10.2020).

[Pro zakinchennia rodovoho vidminka imennykiv III vidminy]

Пропозиції та зауваження до нової редакції проєкту Українського правопису від Правописного семінару імені Олекси Горбача. URL: https://cutt.ly/IfMIVNu (21.04.2020).

[Propozytsii ta zauvazhennia do novoi redaktsii proiektu Ukrainskoho pravopysu vid Pravopysnoho seminaru imeni Oleksy Horbacha]

Русанівський, Віталій М. (ред.) Український правопис: проект. Київ: Наукововидавничий центр Центральної наукової бібліотеки України ім. В.І. Вернадського, 2003.

[Rusanivskyi, Vitalii M. (red.) Ukrainskyi pravopys: proekt. Kyiv: Naukovovydavnychyi tsentr Tsentralnoi naukovoi biblioteky Ukrainy im. V.I. Vernadskoho, 2003] 
Савченко, І.С. Способи реалізації функціонально-стилістичного принципу української пунктуації. [В:] Науковий часопис Національного педагогічного університету ім. М.П. Драгоманова. Серія 10: Проблеми граматики і лексикології української мови. 2012. Випуск 9, 152-155.

[Savchenko, I.S. Sposoby realizatsii funktsionalno-stylistychnoho pryntsypu ukrainskoi punktuatsii. [V:] Naukovyi chasopys Natsionalnoho pedahohichnoho universytetu im. M.P. Drahomanova. Seriia 10: Problemy hramatyky i leksykolohii ukrainskoi movy. 2012. Vypusk 9, 152-155]

Синявський, Олекса. «Коротка історія «Українського правопису»». [В:] Культура українського слова: [збірник Науково-Дослідчого Інституту Т. Шевченка]. Харків; Київ, 1931, 93-112 (https://cutt.ly/NghVy8s (12.02.2020).

[Syniavskyi, Oleksa. «Korotka istoriia «Ukrainskoho pravopysu»». [V:] Kultura ukrainskoho slova: [zbirnyk Naukovo-Doslidchoho Instytutu T. Shevchenka]. Kharkiv; Kyiv, 1931, 93-112]

Смаль-Стоцький, Степан. «Правописна справа». [B:] Літературно-Науковий Вістник. 1926. Т. 90. Кн. 5, 75-81; Кн. 7/8, 312-320.

[Smal-Stotskyi, Stepan. «Pravopysna sprava». [V:] Literaturno-Naukovyi Vistnyk. 1926. T. 90. Kn. 5, 75-81; Kn. 7/8, 312-320]

Степаненко, Микола. «Перифраз і його текстотвірні функції в котляревськознавчому дискурсі Олеся Гончара». [В:] Лінгвістичні дослідження, 2019. Вип. 50, 219-226.

[Stepanenko, Mykola. «Peryfraz i yoho tekstotvirni funktsii v kotliarevskoznavchomu dyskursi Olesia Honchara». [V:] Linhvistychni doslidzhennia, 2019. Vyp. 50, 219-226]

Тараненко, Олександр. «Сучасні тенденції до перегляду нормативних засад української літературної мови і явище пуризму (у межах граматичних категорій іменника)». [В:] Мовознавство. 2005. 3-4, 84-105.

[Taranenko, Oleksandr. «Suchasni tendentsii do perehliadu normatyvnykh zasad ukrainskoi literaturnoi movy i yavyshche puryzmu (u mezhakh hramatychnykh katehorii imennyka)». [V:] Movoznavstvo. 2005. 3-4, 84-105]

Тараненко, Олександр. «Сучасні тенденції до перегляду нормативних засад української літературної мови і явище пуризму (у межах граматичних категорій іменника)». [В:] Мовознавство. 2008. 2-3, 159-189.

[Taranenko, Oleksandr. «Suchasni tendentsii do perehliadu normatyvnykh zasad ukrainskoi literaturnoi movy i yavyshche puryzmu (u mezhakh hramatychnykh katehorii imennyka)». [V:] Movoznavstvo. 2008. 2-3, 159-189]

Ткаченко, Олександр. «До соціолінгвістичної класифікації мов». [В:] Мовознавство. 2005. 3-4, 63-68.

[Tkachenko, Oleksandr. «Do sotsiolinhvistychnoi klasyfikatsii mov». [V:] Movoznavstvo. 2005. 3-4, 63-68]

УП: Український правопис: проєкт. Харків: Державне видавництво України, 1926.

[Ukrainskyi pravopys: proiekt. Kharkiv: Derzhavne vydavnytstvo Ukrainy, 1926]

УП: Український правопис. Харків: Державне видавництво України, 1928.

[Ukrainskyi pravopys. Kharkiv: Derzhavne vydavnytstvo Ukrainy, 1928]

УП: Український правопис. Видання перше. Харків: Державне видавництво України, 1929.

[Ukrainskyi pravopys. Vydannia pershe. Kharkiv: Derzhavne vydavnytstvo Ukrainy, 1929]

УП: Український правопис. Київ: Радянська школа, 1933. 
[Ukrainskyi pravopys. Kyiv: Radianska shkola, 1933]

УП: Український правопис. Вид. 2-е, виправлене і доповнене. Київ: Видавництво Академії наук Української РСР, 1960.

[Ukrainskyi pravopys. Vyd. 2-e, vypravlene i dopjvnene. Kyiv: Vydavnytstvo Akademii nauk Ukrainskoi RSR, 1960]

Український правопис. Київ: Наукова думка, 1993.

[Ukrainskyi pravopys. Kyiv: Naukova dumka, 1993]

Український правопис: проєкт найновішої редакції. Київ: Наукова думка, 1999.

[Ukrainskyi pravopys: proiekt nainovishoi redaktsii. Kyiv: Naukova dumka, 1999]

Український правопис. Київ: Наукова думка, 2019.

[Ukrainskyi pravopys. Kyiv: Naukova dumka, 2019]

Фаріон, Ірина. Український правопис - корсет мови? Український правопис як культурно-політичний вибір. 2004. Львів: Монастир «Свято-Іванівська Лавра», 2004.

[Farion, Iryna. Ukrainskyi pravopys - korset movy? Ukrainskyi pravopys yak kulturno-politychnyi vybir. 2004. Lviv: Monastyr Sviato-Ivanivska Lavra, 2004]

Хвиля, Андрій. «Викорінити, знищити націоналістичне коріння на мовному фронті». [В:] Більшовик України, 1933, 4, 42-56.

[Khvylia, Andrii. «Vykorinyty, znyshchyty natsionalistychne korinnia na movnomu fronti». [V:] Bilshovyk Ukrainy, 1933, 4, 42-56]

Шевельов, Юрій. Українська мова і першій половині двадцятого століття (1900 1941): стан і статус. Чернівці: Рута, 1998.

[Shevelov, Yurii. Ukrainska mova i pershii polovyni dvadtsiatoho stolittia (1900 1941): stan i status. Chernivtsi: Ruta, 1998]

Шевельов, Юрій. Нарис сучасної української літературної мови та інші лінгвістичні студії (1948-1953). Київ: Темпора, 2012.

[Shevelov, Yurii. Narys suchasnoi ukrainskoi literaturnoi movy ta inshi linhvistychni studii (1948-1953). Kyiv: Tempora, 2012]

Ющук, Іван. Український правопис: проєкт. Київ: Видавець Пугач О.В., 2008.

[Yushchuk, Ivan. Ukrainskyi pravopys: proiekt. Kyiv: Vydavets Puhach O.V., 2008]

Danylenko, Andrii. From the Bible to Shakespeare: Pantelejmon Kuliš (1819-97) and the Formation of Liyerary Ukrainian. Boston: Academic Studies Press, 2016.

Karunyk, Kateryna. «The Ukrainian Spelling reforms, half-reforms, non-reforms and anti-reforms as manifestation of the Soviet Language Policy». [In:] Studi Slavistici. 2017. 14(1), 91-110 (https://cutt.ly/afMREoP (21.04.2020)).

\section{Використані джерела}

Авраменко, Олег. Небо, повне зірок. URL: https:/cutt.ly/DfMndst (12.01.2020).

[Avramenko, Oleh. Nebo, povne zirok]

Андрухович, Софія. Літо Мілени. Київ: Смолоскип, 2002.

[Andrukhovych, Sofiia. Lito Mileny. Kyiv: Smoloskyp, 2002]

Андрушко, Тетяна. Весни навідувався птах. Кіровоград: Степова Еллада, 2008.

[Andrushko, Tetiana. Vesny naviduvavsia ptakh. Kirovohrad: Stepova Ellada, 2008]

Багряний, Іван. Тигролови. Новий Ульм: Прометей, 1946.

Bahrianyi, Ivan. Tyhrolovy. Novyi Ulm: Prometei, 1946.

Багряний, Іван. Сад Гетсиманський. Новий Ульм, 1950. 
[Bahrianyi, Ivan. Sad Hetsymanskyi. Novyi Ulm, 1950]

Багряний, Іван. Тигролови. Морітурі. Київ: Наукова думка, 2004.

[Bahrianyi, Ivan. Tyhrolovy. Morituri. Kyiv: Naukova dumka, 2004]

Багряний, Іван. Сад Гетсиманський. Харків: Фоліо, 2017.

[Bahrianyi, Ivan. Sad Hetsymanskyi. Kharkiv: Folio, 2017]

Біблія, переклад Івана Огієнка. URL: http://bible-book.org/ua (20.12.2019).

[Bibliia, pereklad Ivana Ohiienka]

Білкун, Микола. Багато, багато, багато золота... Київ: Молодь, 1975.

[Bilkun, Mykola. Bahato, bahato, bahato zolota... Kyiv: Molod, 1975]

Винничук, Юрій. Мальва Лінда. Харків: Фоліо, 2014.

[Vynnychuk, Yurii. Malva Linda. Kharkiv: Folio, 2014]

Винничук, Юрій. Діви ночі. Харків: Фоліо, 2016.

[Vynnychuk, Yurii. Divy nochi. Kharkiv: Folio, 2016]

Гордасевич, Галина. Степан Бандера: людина і міф. Львів: Агріорі, 2008.

[Hordasevych, Halyna. Stepan Bandera: liudyna i mif. Lviv: Ahriori, 2008]

Дністровий, Анатолій. Місто уповільненої дії. Київ: Факт, 2013.

[Dnistrovyi, Anatolii. Misto upovilnenoi dii. Kyiv: Fakt, 2013]

Домонтович, Віктор. Доктор Серафікус. Харків: Фоліо, 2017.

[Domontovych, Viktor. Doktor Serafikus. Kharkiv: Folio, 2017]

Еллан-Блакитний, Василь. Поезії. Київ: Радянський письменник, 1964.

[Ellan-Blakytnyi, Vasyl. Poezii. Kyiv: Radianskyi pysmennyk, 1964]

Забужко, Оксана. Польові дослідження з українського сексу. Київ: Комора, 2015. [Zabuzhko, Oksana. Polovi doslidzhennia z ukrainskoho seksu. Kyiv: Komora, 2015] Карпа, Ірен. Фройд би плакав. Харків: Фоліо, 2004.

[Karpa, Iren. Froid by plakav. Kharkiv: Folio, 2004]

Косинка, Григорій. В житах. Київ: Державне видавництво України, 1926.

[Kosynka, Hryhorii. V zhytakh. Kyiv: Derzhavne vydavnytstvo Ukrainy, 1926]

Косинка, Григорій. Вибрані твори. Київ: Ранок 2009.

[Kosynka, Hryhorii. Vybrani tvory. Kyiv: Ranok 2009]

Костенко, Ліна. Вибране. Київ: Дніпро, 1989.

[Kostenko, Lina. Vybrane. Kyiv: Dnipro, 1989]

Медвідь, В’ячеслав. Збирачі каміння. Київ: Україна, 2006.

[Medvid, Viacheslav. Zbyrachi kaminnia. Kyiv: Ukraina, 2006]

Олесь, Олександр. Твори: В 2-х т. Київ: Дніпро, 1990.

[Oles, Oleksandr. Tvory: V 2-kh t. Kyiv: Dnipro, 1990]

Ольжич, Олег. Вибрані твори. Київ: Смолоскип, 2009.

[Olzhych, Oleh. Vybrani tvory. Kyiv: Smoloskyp, 2009]

Осьмачка, Тодось. План до двору. Торонто: Український Канадійський Легіон, 1951.

[Osmachka, Todos. Plan do dvoru. Toronto: Ukrainskyi Kanadiiskyi Lehion, 1951]

Осьмачка, Тодось. Поезії. Повісті. Київ: Наукова думка, 2002.

[Osmachka, Todos. Poezii. Povisti. Kyiv: Naukova dumka, 2002]

Підмогильний, Валер'ян. Місто. Київ: Державне видавництво України, 1928.

[Pidmohylnyi, Valerian. Misto. Kyiv: Derzhavne vydavnytstvo Ukrainy, 1928]

Підмогильний, Валер'ян. Місто. Харків: Місто, 2014.

[Pidmohylnyi, Valerian. Misto. Kharkiv: Misto, 2014]

Самчук, Улас. Юність Василя Шеремети. Том 1. Мюнхен: Прометей, 1947.

[Samchuk, Ulas. Yunist Vasylia Sheremety. Tom 1. Miunkhen: Prometei, 1947] 
Самчук, Улас. Юність Василя Шеремети. Харків: Фоліо, 2014.

[Samchuk, Ulas. Yunist Vasylia Sheremety. Kharkiv: Folio, 2014]

СУМ 11: Словник української мови: В 11-ти т. Київ: Наукова думка, 1970 - 1980.

[Slovnyk ukrainskoi movy: V 11-ty t. Kyiv: Naukova dumka, 1970 - 1980]

СУМ 20: Словник української мови: В 20-ти т. Київ: Наукова думка; Український мовно-інформаційний фонд Національної академії наук України, 2010 - 2020.

[Slovnyk ukrainskoi movy: V 20-ty t. Kyiv: Naukova dumka; Ukrainskyi movnoinformatsiinyi fond Natsionalnoi akademii nauk Ukrainy, 2010 - 2020]

Тарасюк, Галина. Цінь-Хуань-Гонь, або Великий перманент. Біла Церква: Буква, 2008.

[Tarasiuk, Halyna. Tsin-Khuan-Gon, abo Velykyi permanent. Bila Tserkva: Bukva, 2008]

Український національний лінгвістичний корпус. URL: https:/cutt.ly/bgbopvg (10.07.2020)

[Ukrainskyi natsionalnyi linhvistychnyi korpus]

Ульяненко, Олесь. Вогненне коло. Харків: Фоліо, 2013.

[Ulianenko, Oles. Vohnenne kolo. Kharkiv: Folio, 2013]

Чемерис, Валентин. Ярославна. Харків: Фоліо, 2013.

[Chemerys, Valentyn. Yaroslavna. Kharkiv: Folio, 2013]

Шевченко, Тарас. Кобзар. Київ: Дніпро, 1988.

[Shevchenko, Taras. Kobzar. Kyiv: Dnipro, 1988]

Шевченко, Тарас. Кобзар. Харків: Клуб сімейного дозвілля, 2017.

[Shevchenko, Taras. Kobzar. Kharkiv: Klub simeinoho dozvillia, 2017]

Анатолиј Захнитко

\title{
ЈЕЗИЧКО-ДРУШТВЕНА ОБЈЕКТИВНО-ДИСКУРСНА МОТИВИСАНОСТ ПРЕСКРИПЦИЈА
}

\author{
Резиме
}

Утврђено је да су специфичности савремених дискурсно-правописних пракси у потпуности мотивисани потребом: 1) да се сачува традиција функционалног статуса прескрипција и покаже њихова квантитативна и квалитативна регулативно-институциона употреба; 2) да се обједине разни правци стандардизације и кодификације одређених графема, синтагми, морфолошких и синтаксичких облика; 3) да се докаже објективни језичко-друштвени статус национално-друштвених прескрипција; 4) да се кумулативно прикажу норматизоване тенденције употребе облика и конструкција; 5) да се у синхроном приказу максимално реализују објективни параметри норматизованих тенденција.

У чланку је описан статус семантичких фактора мотивације савремене морфолошке норме именица и испраћене су њихове корелације и/или одсуство истих са деривационим маркерима и лексичко-граматичким факторима. Утврђена су правила еволуције украјинске правописно-морфолошке норме и приказан је функционални статус објективно-граматичких, институционално-дискурсних и других пракси.

Кључне речи: правописна пракса, дискурс, институционални дискурс, дискурсна пракса, морфолошке норме именица. 